\title{
Effects of IGF-I on cardiac growth and expression of mRNAs coding for cardiac proteins after induction of heart hypertrophy in the rat
}

\author{
Marc Y Donath, Wolfgang Zierhut ${ }^{1}$, Martina A Gosteli-Peter, Christina Hauri, E Rudolf Froesch and Jürgen Zapf \\ Division of Endocrinology and Metabolism, Department of Medicine, University Hospital, CH-8091 Zürich, Switzerland and ${ }^{1}$ former Cardiovascular \\ Research Department, Ciba-Geigy, 4002 Basel, Switzerland
}

(Correspondence should be addressed to J Zapf)

\begin{abstract}
Adult rat cardiomyocytes in long-term culture reexpress several fetal cardiac proteins which also reappear during overload heart hypertrophy in vivo. IGF-I decreases reexpression of some of these proteins and stimulates myofibrillogenesis. IGF-I might therefore contribute to enhancing readaptation of the heart to overload. In order to test this hypothesis, hypertension was induced in male Wistar Kyoto rats by constriction of the left renal artery, and an infusion of $500 \mu \mathrm{g} /$ day of recombinant human IGF-I (rhIGF-I) or vehicle was started after the operation via intraabdominally implanted osmotic minipumps. In the vehicle-treated hypertensive animals body weight gain was reduced after 3, 7 and 14 days, whereas rhIGF-I-treated hypertensive animals continued to gain weight like sham-operated animals. Left ventricular weight and the left, but not the right ventricle/body weight ratio increased more in rhIGF-I- than in vehicle-infused rats. Left ventricular IGF-I mRNA levels remained unchanged after renal clipping in both vehicle- and rhIGF-I-treated rats. However, $\beta$-myosin heavy chain (MHC) mRNA in the left ventricle was 6- to 10-fold increased in clipped controls during the whole postoperative period, and rhIGF-I reduced this increase by more than $50 \%$ on days 7 and 14 . On the first postoperative day, rhIGF-I prevented the decrease (50\%) of $\alpha$-MHC mRNA and the increase (2.5fold) of atrial natriuretic factor mRNA in the left ventricle. Renal clipping did not alter cardiac $\alpha$-actin, but enhanced skeletal $\alpha$-actin mRNA expression in the left ventricle up to 2.5-fold. However, both mRNAs were unaffected by rhIGF-I treatment. Restoration of body weight gain and stimulation of left ventricular cardiac weight by rhIGF-I as well as partial reversion of hypertension-induced changes in cardiac protein expression may reflect beneficial effects contributing to enhance readaptation of the heart to overload.
\end{abstract}

European Journal of Endocrinology 139 109-117

\section{Introduction}

Insulin-like growth factor (IGF)-I exerts specific cardiac effects. In vitro, it stimulates $\beta$-myosin heavy chain (MHC) and skeletal $\alpha$-actin of cultured neonatal cardiac cells $(1,2)$, and it enhances myofibril development and decreases smooth muscle $\alpha$-actin and atrial natriuretic factor (ANF) in long-term cultures of adult rat cardiomyocytes (3, 4). In vivo, IGF-I increases heart weight in normal and hypophysectomized rats (5-8). In particular, IGF-I stimulates $\alpha$ - and $\beta$-MHC and skeletal $\alpha$-actin, major components of myofibrils, and decreases ANF expression (6). Administration of IGF-I has been reported to improve doxorubicin-induced cardiomyopathy (9) and to enhance left ventricular function in normal rats (8) and in rats developing cardiac failure (7, 10). Furthermore, IGF-I limited the reperfusion injury after myocardial ischemia by inhibition of apoptosis and of leukocyte-induced cardiac necrosis in rats (11).
Based on our findings in cultured adult rat cardiomyocytes (3) and on findings reported in the literature we recently proposed an hypothesis to explain the development of overload heart hypertrophy (3) overload increases wall stress. Transforming growth factor- $\beta 1$, basic fibroblast growth factor and catecholamines may subsequently participate in transforming the increased mechanical load into biochemical signals (12-16) which elicit production of scaffold proteins for sarcomerogenesis, such as $\alpha$-actin isoforms $(17,18)$, and upregulation of ANF (19-21), IGF-I (22-25) and type 1 IGF receptors (26). Locally produced IGF-I may then act in an auto-/paracrine manner to induce formation of new myofibrils and to downregulate $\alpha$ actin-isoforms, which are no longer needed as a scaffold, as well as ANF whose diuretic effect is no longer required.

In order to assess the possible functional role of IGF-I in vivo during developing cardiac hypertrophy, 
hypertension was induced in rats by constriction of the left renal artery. Since IGF-I enhances myofibril development $(3,6)$, infusion of exogenous IGF-I might contribute to more rapid and more extensive myofibril building and thus enhance readaptation of the heart to overload.

\section{Materials and methods}

\section{Animals}

Renal hypertension was induced by the Goldblatt method adapted to the rat (27). Male Wistar Kyoto rats weighing $120 \mathrm{~g}$ were used. A silver clip $(0.2 \mathrm{~mm}$ inner diameter) was placed on the left renal artery of 80 rats under halothane anesthesia $(2.5 \%)$. Ten agematched animals were sham-operated. Intraoperatively, Alzet mini osmotic pumps (model 2001, Alza Corp., Palo Alto, CA, USA) filled with recombinant human IGF-I (rhIGF-I, Ciba-Geigy, Basel, Switzerland) in $0.1 \mathrm{~mol} / \mathrm{l}$ acetic acid or with solvent were implanted intraabdominally. Forty-five animals were randomized to receive rhIGF-I $(500 \mu \mathrm{g} /$ day $)$ and 45 to receive solvent (controls). Body weight, heart rate and systolic blood pressure (measured by the tail cuff method) were determined on day 4 and day 1 before operation and on days $1,3,7$, and 14 after operation. Animals with renal clips who failed to develop hypertension (increase of systolic blood pressure by less than $20 \mathrm{mmHg}$ ) after 7 days were excluded from the experiment. One, 3, 7 and 14 days after clipping, animals were anesthetized with halothane and bled by jugular vein catheterization. Sham-operated rats were killed on day 14 . Hearts were rapidly excised, the left and the right ventricle were separated, weighed, immediately frozen in liquid nitrogen and stored at $-80^{\circ} \mathrm{C}$ until RNA isolation.

\section{RNA isolation and Northern blotting}

Total RNA was isolated according to standard procedures (28). Frozen tissue (0.1-0.2 g) was homogenized in a Polytron homogenizer (Brinkman Instruments, Westbury, NY, USA) at $4{ }^{\circ} \mathrm{C}$ in $3 \mathrm{ml}$ ice-cold $4 \mathrm{~mol} / \mathrm{l}$ guanidinium isothiocyanate, $\mathrm{pH} 7.0$, containing $5 \mathrm{mmol} / \mathrm{l}$ sodium citrate, $0.1 \mathrm{~mol} / \mathrm{l} \beta$-mercaptoethanol and $0.5 \%$ sarcosine, and RNA was isolated through a cesium chloride gradient. RNA samples were then dissolved in diethylpyrocarbonate-treated $\mathrm{H}_{2} \mathrm{O}$ and concentrations determined spectrophotometrically at $260 \mathrm{~nm}$.

Twenty micrograms denatured RNA per lane were electrophoresed on a $1 \%$ agarose gel containing $2 \mathrm{~mol} / \mathrm{l}$ formaldehyde, transferred to a nylon membrane (Hybond-N, Amersham International, Amersham, Bucks, UK), and RNA fixed by UV crosslinking. The filters were prehybridized at $37^{\circ} \mathrm{C}$ (for the $\alpha$-MHC probe) or at $42{ }^{\circ} \mathrm{C}$ (for the other probes) for at least $2 \mathrm{~h}$ in a solution containing 25\% ( $\alpha$-MHC prehybridization) or $50 \%$ formamide, $5 \times$ Denhardt's solution $(0.02 \% \mathrm{w} / \mathrm{v}$
Ficoll, $0.02 \% \mathrm{w} / \mathrm{v}$ polyvinyl pyrrolidone), $5 \times \mathrm{SSPE}$ $(20 \times=3.6 \mathrm{~mol} / \mathrm{l} \mathrm{NaCl}, 0.2 \mathrm{~mol} / \mathrm{l}$ sodium phosphate, $0.02 \mathrm{~mol} / \mathrm{l} \mathrm{EDTA} \mathrm{pH} \mathrm{7.7),} \mathrm{0.2 \%} \mathrm{SDS} \mathrm{and} 100 \mu \mathrm{g} / \mathrm{ml}$ heatdenatured salmon sperm DNA. The following cDNA probes were used for hybridization: rat skeletal $\alpha$-actin (410 bp) and cardiac $\alpha$-actin cDNA (500 bp) corresponding to the $3^{\prime}$-untranslated regions (kindly provided by Dr P Gunning, Cell Biology Unit, Children's Medical Research Institute, Wentworthville, Australia); mouse ANF cDNA (700 bp) (kindly provided by Dr K R Chien, Center of Molecular Biology, La Jolla, CA, USA); rat IGF-I cDNA corresponding to the genomic sequences between nucleotide 2054 of exon 1 and nucleotide 868 of exon 5 (kindly provided by Dr J Schwander, Basel, Switzerland); and yeast 18S cDNA (kindly provided by Dr Kolousek, University Hospital Zürich, Switzerland). These cDNA probes were labeled by random primer extension using a commercial kit (Boehringer-Mannheim, Mannheim, Germany) and $\left[\alpha_{-}{ }^{32} \mathrm{P}\right]$ deoxycytidine $5^{\prime}$-triphosphate $(\sim 3000 \mathrm{Ci} / \mathrm{mmol}$, Amersham). The $\alpha$ and $\beta$-MHC mRNAs were identified using specific oligonucleotides corresponding to 20-mers from the 3'-untranslated regions of the MHC mRNAs (29). The probes were synthesized by Microsynth, Windisch, Switzerland. The oligonucleotide probes were labeled at the $5^{\prime}$-end using a commercial kit (BoehringerMannheim) and $\left[\gamma^{-32} \mathrm{P}\right]$ ATP $(\sim 3000 \mathrm{Ci} / \mathrm{mmol}$, Amersham). Hybridization was performed in the same solution as described for prehybridization. Incubation time with the cDNA probes was $48 \mathrm{~h}$ at $42^{\circ} \mathrm{C}$. With the $\alpha$ - and $\beta$-MHC oligonucleotide probes incubations were carried out overnight at $37^{\circ} \mathrm{C}$ and $42{ }^{\circ} \mathrm{C}$ respectively. The filters were washed twice for $15 \mathrm{~min}$ at room temperature in $2 \times \mathrm{SSPE} / 0.1 \%$ SDS and subsequently three times in $0.1 \times \mathrm{SSC} / 0.1 \%$ SDS for $20 \mathrm{~min}$ at $48^{\circ} \mathrm{C}$ (cDNA probes) and $65^{\circ} \mathrm{C}(18 \mathrm{~S}$ cDNA) respectively, or three times in $2 \times \mathrm{SSPE} / 0.1 \%$ SDS for $20 \mathrm{~min}$ at $39^{\circ} \mathrm{C}(\alpha$ $\mathrm{MHC})$ or $42^{\circ} \mathrm{C}(\beta-\mathrm{MHC})$. mRNA levels were quantitated by scanning densitometry using a BioRad video densitometer (Richmond, CA, USA). Variations of gel loading were corrected by normalization for the corresponding $18 \mathrm{~S}$ ribosomal RNA values.

\section{IGF-I determination}

Serum IGF-I (endogenous or infused) was separated from IGF-binding proteins by chromatography of $0.1 \mathrm{ml}$ serum (adjusted to $0.25 \mathrm{ml}$ with $\mathrm{PBS} / 0.2 \% \mathrm{HSA}$ ) on Sep-Pak C18 cartridges (Waters, Millipore, Milford, MA, USA) according to the protocol provided by the supplier (Immunonuclear, Stillwater MN, USA). After reconstitution with $1 \mathrm{ml} \mathrm{PBS} / 0.2 \% \mathrm{HSA}, \mathrm{pH} 7.4$, samples were assayed at three different dilutions (1:5, 1:10, 1:20), using two different RIAs. In the first RIA, immunoreactive rat IGF-I was determined using a rabbit antihuman IGF-I antiserum (gift from the late Dr Reber, Hofmann-La Roche, Basel, Switzerland) at a final dilution of 1:20 000 (30) and rat IGF-I as a standard 
(gift from Dr M Kobayashi, Fujisawa Pharmaceutical Co., Osaka, Japan). In the second RIA, infused rhIGF-I was measured with a rabbit anti-human IGF-I antiserum (produced by our laboratory) (31) which does not crossreact with rat IGF-I at the dilutions used, and rhIGFI (Ciba-Geigy AG) as a standard. ${ }^{125} \mathrm{I}-\mathrm{rhIGF}-\mathrm{I}(\sim 350 \mathrm{Ci} / \mathrm{g}$; Anawa, Wangen, Switzerland) was used as a tracer. After preincubation of the antisera $(0.2 \mathrm{ml})$ with standards or samples $(0.1 \mathrm{ml})$ for $24 \mathrm{~h}$ at $4{ }^{\circ} \mathrm{C},{ }^{125} \mathrm{I}$-rhIGF-I $(30-$ 40000 c.p.m., $0.1 \mathrm{ml}$ ) was added, and incubation was continued for another $24 \mathrm{~h}$, before precipitation with the second antibody (goat anti-rabbit immune globulin antiserum) was carried out (31).

In the rat IGF-I RIA, rhIGF-I crossreacts 5- to 10-fold better than rat IGF-I in a non-parallel fashion. Therefore, total (human + rat) IGF-I levels in the rhIGFinfused animals cannot be measured. Infusion of normal rats with $1 \mathrm{mg} /$ rat per day rhIGF-II, which does not crossreact in the rat IGF-I RIA, results in $36.8 \pm 11 \%$ suppression of endogenous rat IGF-I ( $\mathrm{J}$ Zapf, unpublished observations). As an approximation, rhIGF-I can be assumed to cause a similar suppression of endogenous IGF-I as rhIGF-II. Assuming a linear relationship between dose and suppressive effect, $0.5 \mathrm{mg} /$ rat per day would cause an $\sim 18-19 \%$ reduction of endogenous IGF-I. Therefore, total IGF-I levels in our rhIGF-I-infused animals can be estimated by adding $\sim 80 \%$ of the endogenous IGF-I value determined in vehicle-treated rats to the rhIGF-I levels determined under rhIGF-I treatment.

\section{Statistical analysis}

The results for different groups of animals are expressed as means \pm s.E.M. Comparisons of curves were performed using area under curve determinations as described previously (32). The statistical significance was determined by Student's $t$-test for comparisons between rhIGF-I-treated and untreated animals of each treatment day and for comparisons between the various treatment days and untreated controls on day 0 .

\section{Results}

\section{Serum IGF-I levels}

Endogenous (rat) serum IGF-I levels in clipped hypertensive animals were $1375 \pm 124,1389 \pm 134,1496 \pm$ 135 and $1559 \pm 127 \mathrm{ng} / \mathrm{ml}$ on days $1,3,7$ and 14 after renal clipping. During rhIGF-I infusion, exogenous rhIGF-I serum levels as determined with the human IGF-I RIA 1, 3, 7 and 14 days after renal clipping were $1201 \pm 145, \quad 906 \pm 152, \quad 928 \pm 137$ and $920 \pm$ $142 \mathrm{ng} / \mathrm{ml}$ respectively. As mentioned above, these latter values only reflect infused, but not total, i.e. endogenous rat IGF-I + exogenous rhIGF-I. According to the explanation given in Materials and Methods, total
IGF-I levels during rhIGF-I treatment can be estimated to lie between 2000 and $2300 \mathrm{ng} / \mathrm{ml}$.

\section{Systemic arterial pressures and heart rates}

Clipping of the left renal artery significantly increased the systemic arterial blood pressure of both control and rhIGF-I-treated animals on day 1 (Fig. 1A). Blood pressure increased further on days 3, 7 and 14. Heart rate decreased 1 and 3 days after constriction of the left renal artery but increased again later and was comparable to that in sham-operated animals on days 7 and 14 (Fig. 1B). No significant changes were observed in sham-operated animals. Treatment with rhIGF-I had no significant influence on blood pressure or heart rate in the clipped animals.

\section{Growth parameters}

Hypertension reduced body weight gain significantly after 3, 7 and 14 days as compared with sham-operated rats (Fig. 2A). In contrast, body weight of clipped rhIGFI-treated animals continued to increase as in shamoperated rats (Fig. 2A). In rhIGF-I-treated hypertensive rats, left ventricular weights were greater than in clipped controls (Fig. 2B). The same was true for the left ventricle/body weight ratio (Fig. 2C). After 14 days all clipped animals had a higher left ventricle/body weight ratio than the corresponding group of sham-operated rats (Fig. 2C). rhIGF-I did not change left ventricle/body weight ratio of sham-operated rats. Right ventricle/body weight ratios were similar in all groups of rats (not shown).

\section{Effects of rhIGF-I on mRNA expression of $\alpha$ - and $\beta$-MHC, ANF, skeletal and cardiac $\alpha$-actin, and IGF-I}

Hypertension stimulated $\beta$-MHC mRNA expression in the left ventricle 6 - to 10 -fold during the whole postoperative period. Under rhIGF-I treatment, $\beta$-MHC mRNA expression was significantly reduced between days 7 and 14 (Fig. 3B). $\beta$-MHC mRNA expression increased much less $(\sim 2$-fold $)$ in the right ventricle and was not altered by rhIGF-I (not shown).

$\alpha$-MHC mRNA expression in the left ventricle decreased by $50 \%$ on the first postoperative day in the untreated, but not in the rhIGF-I-treated hypertensive animals (Fig. 3A). At later time points (up to 7 days), $\alpha$-MHC mRNA expression was not significantly different from preoperative levels and was not affected by rhIGF-I. After 14 days expression tended to decrease in both hypertensive and sham-operated animals.

ANF mRNA expression increased 2.5-fold after renal clipping and persisted throughout the whole postoperative period (Fig. 3C). The increase was prevented by rhIGF-I on the first postoperative day, but not later on. 
Skeletal $\alpha$-actin mRNA was stimulated 1.5- to 2.5fold in hypertensive rats. However, it was not influenced by rhIGF-I at any time point (Fig. 3D). Left ventricular cardiac $\alpha$-actin and IGF-I mRNA expression (Fig. 3E and F) did not significantly change during hypertension with or without rhIGF-I treatment.

\section{Discussion}

The purpose of the present study was to assess the effects of rhIGF-I treatment on the heart in rats exposed to cardiac overload after constriction of the left renal artery. One of the most obvious features following the increase in blood pressure was a significant reduction in body weight gain which manifested itself 3 days after renal clipping and persisted throughout the whole postoperative period. rhIGF-I treatment restored body weight gain to that of untreated sham-operated animals. It also caused a greater increase of the left ventricular weight in hypertensive as well as in shamoperated animals as compared with the corresponding untreated groups. Furthermore, the left ventricle/body weight ratio increased more in rhIGF-I-treated than in untreated hypertensive rats. In both the rhIGF-treated and the untreated hypertensive group this ratio was significantly higher than in rhIGF-I-treated or untreated sham-operated animals. The increased left ventricle/ body weight ratio during rhIGF-I treatment of the hypertensive animals may reflect a greater capacity of the left ventricle to cope with cardiac overload.
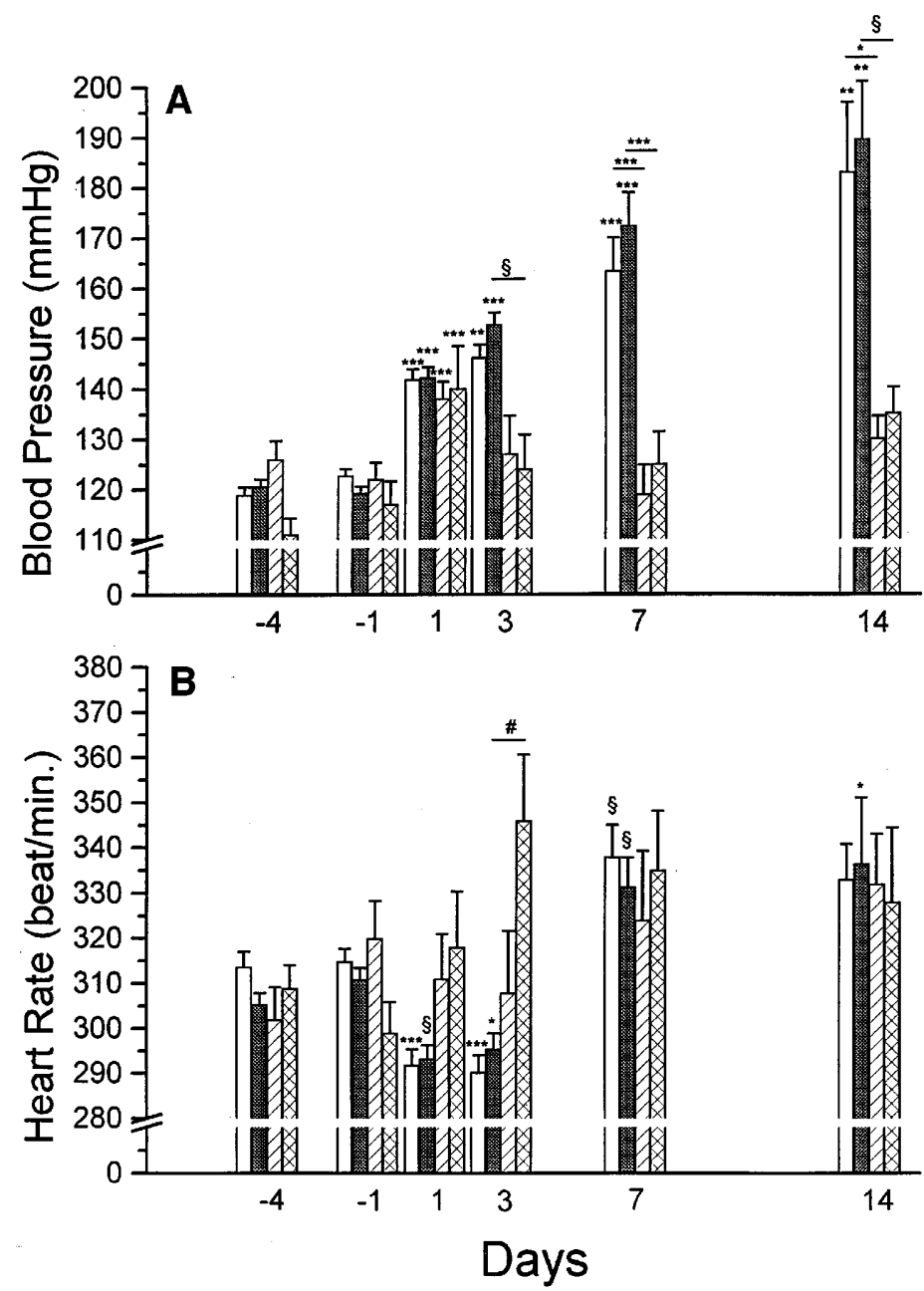

Figure 1 Systemic arterial blood pressure (A) and heart rate (B) of hypertensive rats treated with vehicle (clip, open columns) or $500 \mu \mathrm{g} / \mathrm{day}$ of rhIGF-I (clip + rhlGF-I, solid columns) from days 0 to 14 and of age-matched sham-operated animals treated with vehicle (hatched columns) or rhIGF-I for 14 days (cross-hatched columns). Hypertension was induced by renal artery clipping (day 0 ). The number of clipped rats in each group on days 1, 3, 7 and 14 was 10,10, 9, 8 for vehicle-treated and 10, 10, 6, 7 for rhIGF-I-treated animals. Ten age-matched animals were sham-operated, five were treated with vehicle and five with rhIGF-I. Points give mean values and bars the S.E.M. $P$ values between each time point and day -1 are given on top of each column. $P$ values comparing different treatments on each day are marked by horizontal bars; ${ }^{*}<0.05, \#<0.02, \S<0.01,{ }^{* *}<0.001,{ }^{* * *}<0.0001$. 
The first detectable changes in cardiac gene expression during heart hypertrophy due to cardiac overload are reflected by the activation of a program of immediate early genes such as c-fos, c-jun and egr-1 (16). These changes are rapid and transient and are followed by reexpression of genes normally 'active' only in the fetal ventricle, such as the $\beta$-MHC, the skeletal $\alpha$ actin or the ANF gene, and by induction of genes coding for contractile proteins, such as cardiac $\alpha$-actin (16). At the same time, $\alpha$-MHC gene expression is downregulated. These latter changes persist during myocardial cell hypertrophy. In our rats, $\beta$-MHC, ANF and skeletal $\alpha$-actin mRNA expression increased significantly after renal artery constriction and the subsequent rise in blood pressure, but cardiac $\alpha$-actin mRNA levels remained unchanged. $\beta$-MHC mRNA increased 6 - to 10 -fold and stayed elevated during the whole postoperative period. In contrast, $\alpha$-MHC mRNA expression did not significantly change postoperatively, apart from a transient fall on the first postoperative day, which was prevented by rhIGF-I. $\beta$-MHC upregulation has been shown to correlate with overload (33). Therefore, the
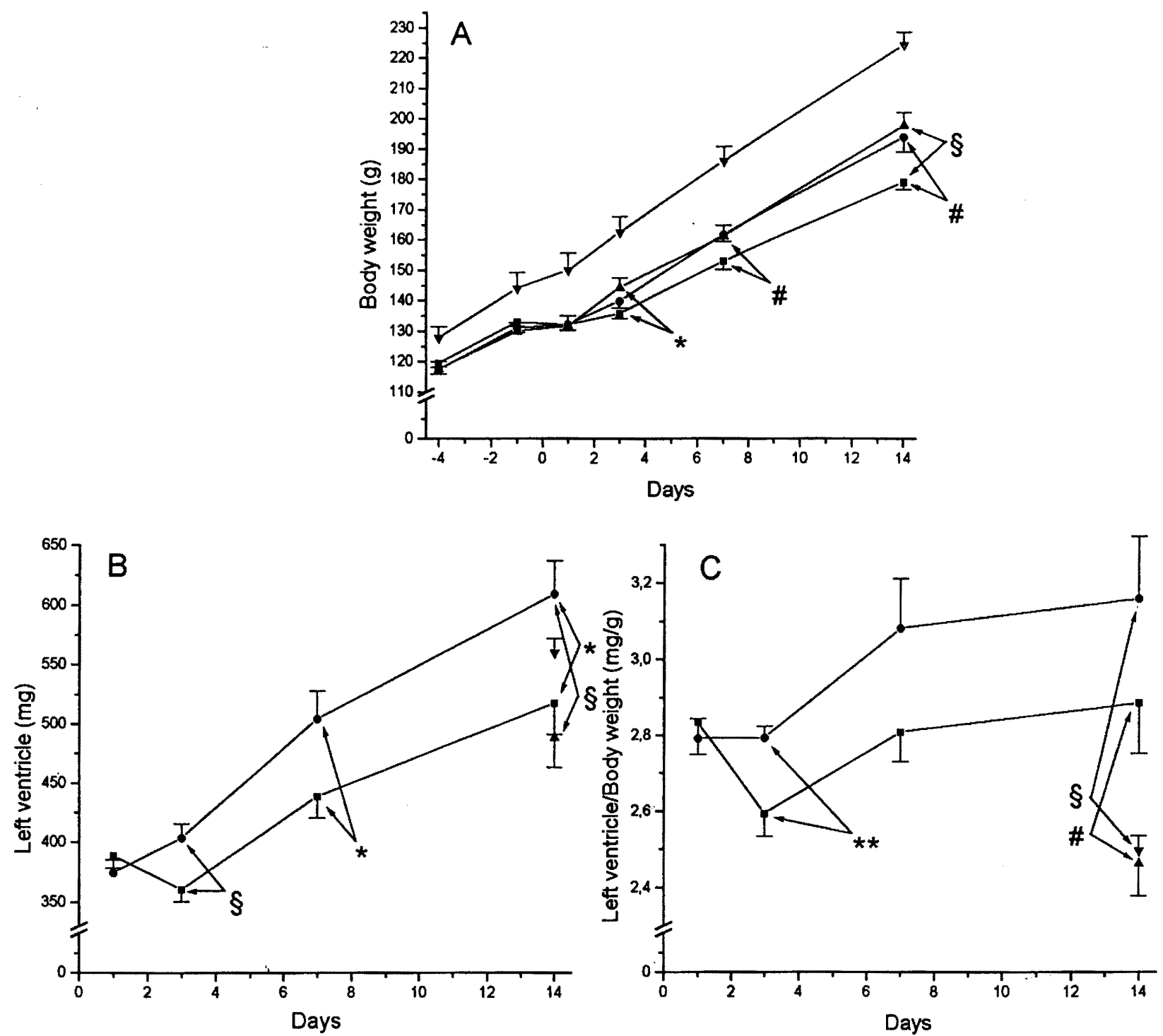

Figure 2 Body weight (A), left ventricular weight (B) and left ventricle/body weight ratio (C) of hypertensive rats treated with vehicle (clip) or $500 \mu \mathrm{g} /$ day rhIGF-I (clip + rhlGF-I) from days 0 to 14 and of age-matched sham-operated animals treated with vehicle or rhIGF-I for 14 days (sham and sham + rhIGF-I). Hypertension was induced by renal artery clipping (day 0 ). The number of clipped rats in each group on days 1 , 3,7 and 14 was $10,10,9,8$ (vehicle $\mathbf{a}$ ) and 10,10, 6, 7 (rhlGF-I-treated $\bullet$ ). Ten age-matched animals were sham-operated, five were treated with vehicle $(\boldsymbol{\Lambda})$ and five with rhIGF-I $(\mathbf{\nabla})$. Points give mean values and bars the S.E.M. Significant $P$ values for corresponding time points are marked: ${ }^{*}<0.05, \#<0.02, \S<0.01,{ }^{* *}<0.001$. $P$ values for differences between the areas under the curves of clipped control rats and clipped rats treated with rhIGF-I in (B) and (C) were $<0.008$ and $<0.02$ respectively. 

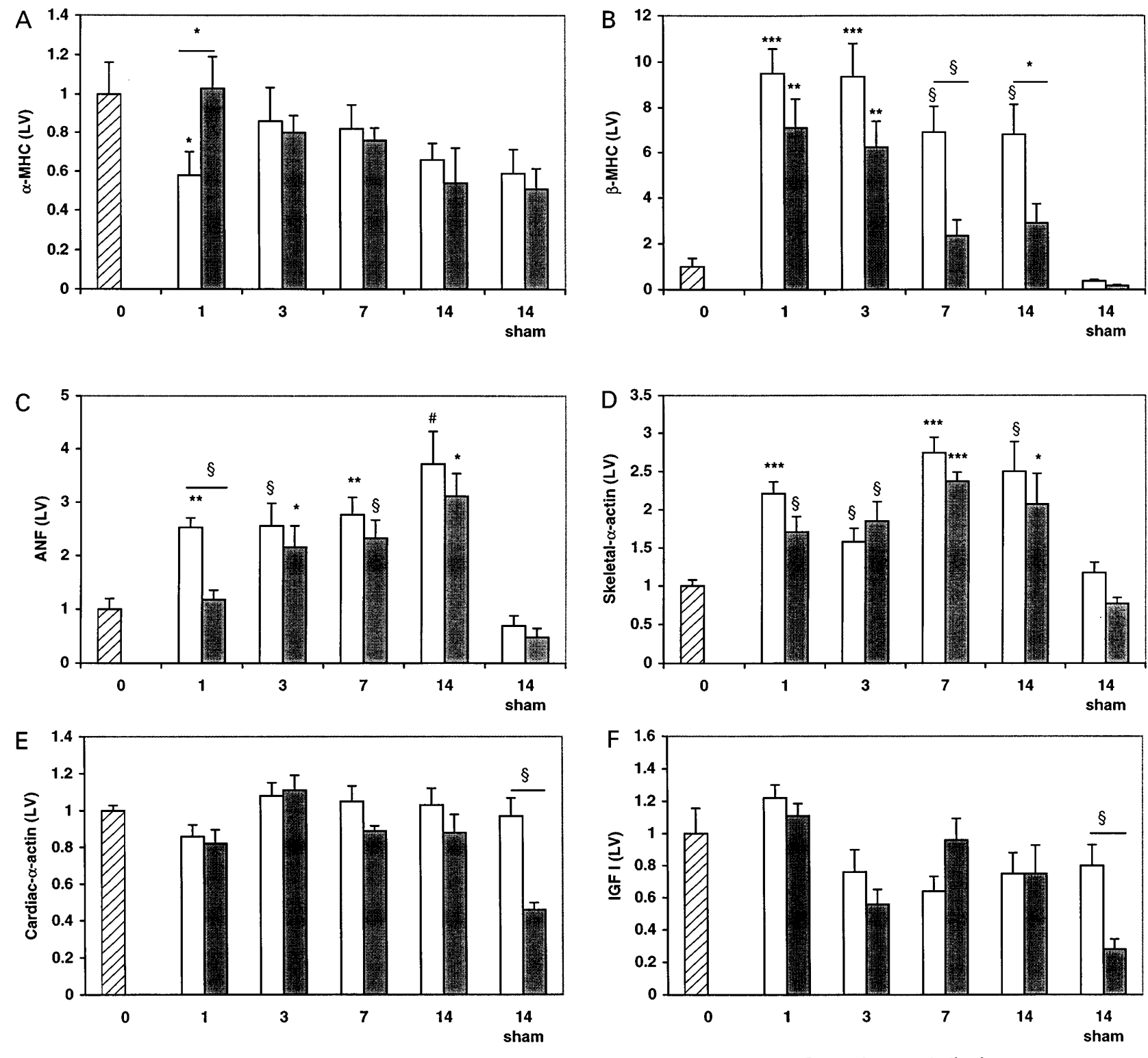

Figure 3 mRNA expression of left ventricular (LV) $\alpha$-MHC (A), $\beta$-MHC (B), ANF (C), skeletal $\alpha$-actin (D), cardiac $\alpha$-actin (E) and IGF-I (F) in hypertensive rats treated with vehicle (open bars) or $500 \mu \mathrm{g} /$ day of rhlGF (solid bars) from days 0 to 14 , and in age-matched shamoperated animals (sham). Hypertension was induced by renal artery clipping (day 0). Twenty micrograms total RNA from the left ventricle of each rat was electrophoresed (separate gels for each treatment day including rhIGF-I-treated and untreated hypertensive animals, and untreated controls from day 0 ), transferred to a nylon membrane and hybridized as described in Materials and methods. Membranes were stripped $\left(0.1 \times \mathrm{SSC} / 0.1 \% \mathrm{SDS}\right.$ at $\left.90^{\circ} \mathrm{C}, 60 \mathrm{~min}\right)$ before rehybridization with the next probe. Quantification of the hybridization signals was performed by scanning densitometry. Data were corrected for the corresponding $18 \mathrm{~S}$ ribosomal RNA values. The values of the untreated controls at day 0 were taken as 1.0. The number of rats in each group on days $1,3,7$ and 14 was 10, 10, 9, 8 for untreated and 10, 10, 6, 7 for rhIGF-I-treated hypertensive animals. Five animals each (age-matched) were sham-operated and treated for 14 days with vehicle or rhIGF-I (sham). Five animals (age-matched) were killed on day 0 (untreated controls; hatched bars). $P$ values between each time point and day 0 are given on top of each bar. $P$ values comparing untreated and rhIGF-I-treated hypertensive rat are marked by horizontal lines; ${ }^{*}<0.05, \#<0.02, \S<0.01,{ }^{* *}<0.001,{ }^{* \star *}<0.0001$. (G, opposite page) A representative Northern blot. Twenty micrograms total RNA from the left ventricles (pooled from rats of each treatment group and day) were electrophoresed, transferred to a nylon membrane and hybridized as described in Materials and methods. The same membrane was used for sequential hybridization with each probe after stripping (see above), which removed previous hybridization signals. 
G
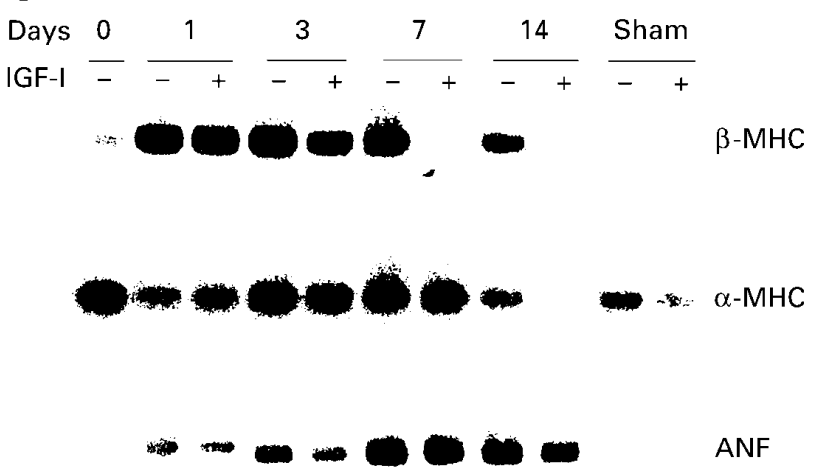

ANF

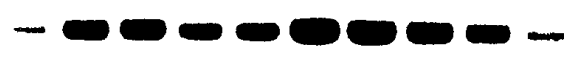

Skeletal $\alpha$-actin
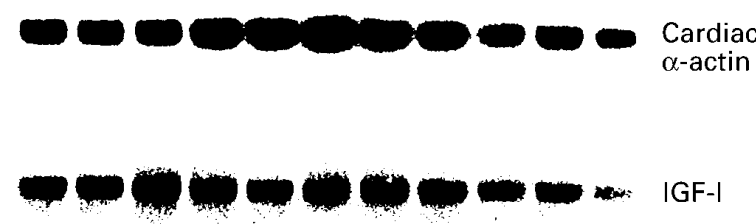

IGF-I

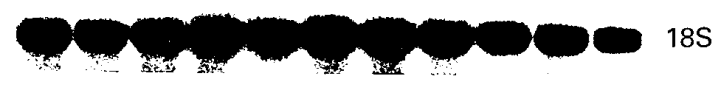

Figure 3 (Continued)

pronounced suppression of $\beta$-MHC by rhIGF-I treatment on day 7 and 14 after renal clipping may indicate that, by that time, the left ventricle was able to better compensate the overload than in the untreated hypertensive group. The greater left ventricular weight and the greater left ventricle/body weight ratio in the rhIGF-I-treated hypertensive animals point in the same direction. Although the lower adenosine triphosphatase activity of $\beta$ - as compared with $\alpha$-MHC may convey greater economy to contraction because of thermodynamic advantages (34), it is associated with diminished myocardial contractility (35). The reduction of $\beta$-MHC expression by rhIGF-I in the presence of unchanged $\alpha$-MHC expression, which results in a more 'physiological' $\alpha$ - to $\beta$-MHC ratio than in the untreated hypertensive animals, may thus reflect a more favorable balance between economy of contraction and contractility and possibly a better readaptation to pressure overload. The cellular and molecular mechanisms potentially responsible for the additional enlargement of the left ventricular mass after rhIGF-I treatment are likely to be directly mediated by IGF-I.

IGF-I induces formation of new myofibrils in cultured adult rat cardiomyocytes (3) and stimulates myofibrillar gene expression in normal rats in vivo (6). Therefore, IGF-I may enhance the effect of hypertrophy on the increase of left ventricular mass.

Ventricular ANF and skeletal $\alpha$-actin are considered as 'fetal' cardiac proteins which are reexpressed during heart hypertrophy (18-21). Both ANF and skeletal $\alpha-$ actin mRNA increased significantly after renal clipping and stayed elevated during the whole postoperative period. rhIGF-I did not significantly influence the increase in skeletal $\alpha$-actin. The suppression by rhIGF-I of the increase in left ventricular ANF on the first postoperative day is in line with results obtained in longterm cultures of adult rat cardiomyocytes (4) and in normal (normotensive) rats (6). However, later during hypertension the suppressive effect of rhIGF-I disappeared. It may have been overridden by the continuous hypertensive stimulus on ANF expression. Indeed, it has been shown that activation of ventricular mRNA expression does not only depend on left ventricular enddiastolic pressure, which may be the potential trigger of this activation at early stages after renal clipping, but also on the development of hypertrophy (21).

One of the surprising findings, which contrasts with reports in the literature $(21-25)$, was that pressure overload did not significantly enhance left ventricular IGF-I expression. Upregulation of IGF-I as reported in the literature (22-25) occurred at different times after the onset of hypertension. In one study (22) a 5-fold increase of left ventricular IGF-I mRNA was observed 4 days after renal artery clipping, but not after 2 or 7 days. Following unilateral nephrectomy, IGF-I mRNA expression increased 8 -fold after 3 weeks and persisted up to 6 weeks (25). A more modest (50\%) enhancement of IGF-I mRNA expression was reported 7 and 21 days after aortic banding (24), and a 4-fold rise was noted in the right ventricle 35 days after induction of chronic hypoxia (23). The failure to detect significant changes of IGF-I mRNA expression in our hypertensive rats might therefore be explained by the fact that we either missed a transient rise during the course of the experiment or that hypertension did not last long enough to cause a significant rise.

Previous reports have shown beneficial effects of IGF-I on the heart; doxorubicin-induced cardiomyopathy is improved (9), and left ventricular function is enhanced in normal rats (8) and in rats developing cardiac failure (7). In vitro, IGF-I enhances the contractility of cultured neonatal rat cardiomyocytes (36) and exerts positive inotropic effects on the isolated perfused rat heart $(37,38)$. We have recently shown that IGF-I also has positive inotropic effects on the heart of normal human subjects; it improves cardiac performance with a significant increase in stroke volume, cardiac output and the ejection fraction (39). Similar observations were made in patients with heart failure (40). The rhIGF-I-induced changes in the hearts of our hypertensive rats may reflect beneficial effects contributing to enhance readaptation of the heart to overload. 


\section{Acknowledgements}

This work was supported by the Swiss National Science Foundation (grant 32-31281.91 and 32-46808.96). We should like to thank Mrs I Buclin for her excellent secretarial help.

\section{References}

1 Florini JR \& Ewton DZ. Induction of gene expression in muscle by the IGFs. Growth Regulation 19922 23-29.

2 Ito H, Hiroe M, Hirata Y, Tsujino M, Adachi S, Schichiri M, Koike A, Nogami A \& Marumo F. Insulin-like growth factor-I induces hypertrophy with enhanced expression of muscle specific genes in cultured rat cardiomyocytes. Circulation 1993871715 1721.

3 Donath MY, Zapf J, Eppenberger-Eberhardt M, Froesch ER \& Eppenberger HM. Insulin-like growth factor I stimulates myofibril development and decreases smooth muscle alpha actin of adult cardiomyocytes. Proceedings of the National Academy of Sciences of the USA 199491 1686-1690.

4 Harder BA, Schaub MC, Eppenberger HM \& EppenbergerEberhardt M. Influence of fibroblast growth factor (bFGF) and insulin-like growth factor (IGF-I) on cytoskeletal and contractile structures and on atrial natriuretic factor (ANF) expression in adult rat cardiomyocyte culture. Journal of Molecular and Cellular Cardiology 199628 19-31.

5 Guler H-P, Zapf J, Scheiwiller E \& Froesch ER. Recombinant human insulin-like growth factor I stimulates growth and has distinct effects on organ size in hypophysectomized rats. Proceedings of the National Academy of Sciences of the USA 1988854889 4893

6 Donath MY, Gosteli-Peter MA, Froesch ER \& Zapf J. Insulin-like growth factor I stimulates myofibrillar genes and modulates atrial natriuretic factor mRNA in rat heart. European Journal of Endocrinology 1997137 309-315.

7 Duerr RL, Huang S, Miraliakbar HR, Clark R, Chien KR \& Ross J. Insulin-like growth factor-I enhances ventricular hypertrophy and function during the onset of experimental cardiac failure Journal of Clinical Investigation 199595 619-627.

8 Cittadini A, Strömer H, Katz SE, Clark R, Moses AC, Morgan JP \& Douglas PS. Differential cardiac effects of growth hormone and insulin-like growth factor-I in the rat: a combined in vivo and in vitro evaluation. Circulation 199693 800-809.

9 Ambler GR, Johnston BM, Maxwell L, Gavin JB \& Gluckman PD. Improvement of doxorubicin induced cardiomyopathy in rats treated with insulin-like growth factor I. Cardiovascular Research 199327 1368-1373.

10 Ross J Jr \& Hongo M. The role of hypertrophy and growth factors in heart failure. Journal of Cardiac Failure 19962 S121S128.

11 Buerke M, Murohara T, Skurk C, Nuss C, Tomaselli K \& Lefer AM. Cardioprotective effect of insulin-like growth factor I in myocardial ischemia followed by reperfusion. Proceedings of the National Academy of Sciences of the USA 199592 8031-8035.

12 Parker TG, Packer SE \& Schneider MD. Peptide growth factors can provoke 'fetal' contractile protein gene expression in rat cardiac myocytes. Journal of Clinical Investigation 199085 507-514.

13 Schneider MD \& Parker TG. Cardiac myocytes as targets for the action of peptide growth factors. Circulation $1990811443-$ 1456.

14 Morgan HE, Gordon EE, Kira Y, Chua BHL, Russo LA, Peterson CJ, McDermott PJ \& Watson PA. Biochemical mechanisms of cardiac hypertrophy. Annual Review of Physiology 198749 533-543.

15 Parker TG, Chow K-L, Schwartz RJ \& Schneider MD. Differential regulation of skeletal alpha-actin transcription in cardiac muscle by two fibroblast growth factors. Proceedings of the National Academy of Sciences of the USA 199087 7066-7070.
16 Chien KR, Knowlton KU, Zhu H \& Chien S. Regulation of cardiac gene expression during myocardial growth and hypertrophy: molecular studies of an adaptive physiologic response. FASEB Journal 19915 3037-3046.

17 Black FM, Packer SE, Parker TG, Michael LH, Roberts R, Schwartz RJ \& Schneider MD. The vascular smooth muscle $\alpha$-actin is reactivated during cardiac hypertrophy provoked by load. Journal of Clinical Investigation $1991 \mathbf{8 8}$ 1581-1588.

18 Schwartz K, de la Bastie D, Bouveret P, Oliviéro P, Alonso S \& Buckingham M. $\alpha$-Skeletal muscle actin mRNAs accumulate in hypertrophied adult rat hearts. Circulation Research 198659 551-555.

19 Lattion AL, Michel J-B, Arnauld E, Corvol P \& Sourbier F. Myocardial recruitment during ANF mRNA increase with volume overload in the rat. American Journal of Physiology 1986251 H890-H896.

20 Izumo S, Nadal-Ginard B \& Mahdavi V. Protooncogene induction and reprogramming of cardiac expression produced by pressure overload. Proceedings of the National Academy of Sciences of the USA 198885 339-343.

21 Mercadier J-J, Samuel J-L, Michel JB, Zongazo MA, de la Bastie D, Lompre A-M, Wisnewsky C, Rappaport L, Levy B \& Schwartz K. Atrial natriuretic factor gene expression in rat ventricle during experimental hypertension. American Journal of Physiology 1989 257 H979-H987.

22 Wåhlander H, Isgaard J, Jennische E \& Friberg P. Left ventricular insulin-like growth factor I increases in early renal hypertension. Hypertension 199219 25-32.

23 Russell-Jones DL, Leach RM, Ward JPT \& Thomas CR. Insulin-like growth factor-I gene expression is increased in the right ventricular hypertrophy induced by chronic hypoxia in the rat. Journal of Molecular Endocrinology 199310 99-102.

24 Hanson MC, Fath KA, Alexander RW \& Delafontaine P. Induction of cardiac insulin-like growth factor I gene expression in pressure overload hypertrophy. American Journal of the Medical Sciences 1993306 69-74.

25 Donohue TJ, Dworkin LD, Lango MN, Fliegner K, Lango RP, Benstein JA, Slater WR \& Catanese VM. Induction of myocardial insulin-like growth factor-I gene expression in left ventricular hypertrophy. Circulation 199489 799-809.

26 Toyozaki T, Hiroe M, Hasumi M, Horie T, Hosoda S, Tsushima T \& Sekiguchi M. Insulin-like growth factor I receptors in human cardiac myocytes and their relation to myocardial hypertrophy. Japanese Circulation Journal 199357 1120-1127.

27 Leenen FH \& De Jong W. A solid silver clip for induction of predictable levels of renal hypertension in the rat. Journal of Applied Physiology 197131 142-148.

28 Maniatis T, Fritsch EF \& Sambrook J. Molecular Cloning: A Laboratory Manual, pp 194-195. Cold Spring Harbor: Cold Spring Harbor Laboratory Press, 1982.

29 Gustafson TA, Markham BE \& Morkin E. Analysis of thyroid hormone effects on myosin heavy chain gene expression in cardiac and soleus muscles using a novel dot-blot mRNA assay. Biochemical and Biophysical Research Communications 1985130 1161-1167.

30 Zapf J, Hauri C, Waldvogel M, Futo E, Häsler H, Binz K, Guler HP, Schmid C \& Froesch ER. Recombinant human insulin-like growth factor I induces its own specific carrier protein in hypophysectomized and diabetic rats. Proceedings of the National Academy of Sciences of the USA 198986 38133817.

31 Zapf J, Walter H \& Froesch ER. Radioimmunological determination of insulin-like growth factors I and II in normal subjects and in patients with growth disorders and extrapancreatic tumor hypoglycemia. Journal of Clinical Investigation 198168 13211330.

32 Tai MM. A mathematical model for the determination of total area under glucose tolerance and other metabolic curves. Diabetes Care 199417 152-154. 
33 Izumo S, Lompré A-M, Matsuoka R, Koren G, Schwartz K, NadalGinard B \& Mahdavi V. Myosin heavy chain messenger RNA and protein isoform transitions during cardiac hypertrophy. Journal of Clinical Investigation 198779 970-977.

34 Stephens NL \& Swynghedauw BC. Cardiovascular adaptations to mechanical overload. Molecular and Cellular Biochemistry 199093 $1-6$.

35 Schiaffino S, Samuel JL, Sassoon D, Lompre AM, Garner I, Marotte F, Buckingham M, Rappaport L \& Schwartz K. Nonsynchronous accumulation of alpha-skeletal actin and beta-myosin heavy chain mRNAs during early stages of pressure-overload - induced cardiac hypertrophy demonstrated by in situ hybridization. Circulation Research 198964 937-948.

36 Vetter U, Kupferschmid C, Lang D \& Pentz S. Insulin-like growth factors and insulin increase the contractility of neonatal rat cardiocytes in vitro. Basic Research in Cardiology 198883 647-654.

37 Johnston DM, Gluckman PD, Bratt CM, Ambler GR \& Lubbe WF. Insulin-like growth factors elicit positive inotropic responses in isolated rat heart. Growth Regulation 1994444.
38 Freestone NS, Ribaric S \& Mason WT. The effect of insulin-like growth factor-I on adult rat cardiac contractility. Molecular and Cellular Biochemistry 1996 163-164 223-229.

39 Donath MY, Jenni R, Brunner H-P, Anrig M, Kohli S, Glatz Y \& Froesch ER. Cardiovascular and metabolic effects of insulin-like growth factor I at rest and during exercise in humans. Journal of Clinical Endocrinology and Metabolism 199681 4089-4094

40 Donath MY, Sütsch G, Yan XW, Piva B, Brunner HP, Glatz Y, Zapf J, Follath F, Froesch ER \& Kiowski W. Cardiovascular effects of insulin-like growth factor I in patients with chronic heart failure. Proceedings of the 79th Annual Meeting of the Endocrine Society, June 11-14, 1997, Minneapolis, USA (Abstract OR 12-6). p 81. Program and Abstracts, The Endocrine Society.

Received 27 November 1997

Accepted 19 March 1998 